\title{
STUDI KUALITATIF TENTANG AKTIVITAS ETNOMATEMATIKA DALAM KEHIDUPAN MASYARAKAT TOLAKI
}

\author{
Oleh: Sitti Fatimah S. Sirate ${ }^{*}$
}

\begin{abstract}
The article aims at discovering the form of ethnomathematics activity that exist in Tolaki society at Southeast Sulawesi. This study is a qualitative descriptive research that describe 6 basic activities of Tolaki's society (1) counting, (2) measuring, (3) deciding location, (4) designing, (5) playing, (6) explaining. The data collection was conducted through observation, interview, and documentation. The data were then analyzed based on logical analysis. The results of the research shows that Tolaki society still maintain the traditional of kalo sara which is part of the six basic activities of Tolaki society well known as ethnomathematics. The writer expected that the Tolaki culture should be maintained as local culture heritage that enrich the national culture.
\end{abstract}

KEYWORDS: Ethnomatematics, activity, qualitative study, Tolaki Ethnique.

TIDAK dapat dipungkiri bahwa salah satu keunikan bangsa Indonesia yang tidak dimiliki oleh bangsa-bangsa lain di dunia adalah warisan multietnik dan multikultur. Keberagaman etnik yang hingga kini mencapai lebih dari 500 etnik yang menggunakan 250 bahasa $^{1}$ dan 13.667 pulau, 1.000 pulau yang didiami, ${ }^{2}$ merupakan kekayaan bangsa yang mesti dipelihara dan dikelola dengan mengedepankan nilai-nilai kemajemukan sehingga masing-masing etnik bukan berdiri sebagai entitas yang tertutup dan independen melainkan saling berinteraksi satu sama lain dan saling bergantung serta saling mempengaruhi satu sama lain. ${ }^{3}$ Prinsip "Bhineka Tunggal Ika" seperti yang disebutkan di atas seharusnya dapat dijadikan kunci pembuka interaksi sosial sehingga terbangun suatu pemahaman lintas budaya ${ }^{4}$ dan rasa percaya pada setiap pihak yang terlibat dalam interaksi itu, yang merupakan modal sosial bagi terbentuknya suatu hubungan antar etnik-antar budaya yang sehat, sejahtera dan maju. ${ }^{5}$ Dengan demikian, hidup dalam keberagaman dapat dipandang sebagai

*Magister Pendidikan dari UNM ini adalah dosen LB Pendidikan Matematika di UIN Alauddin dan dosen tetap pada STKIP YPUP Makassar. 
suatu kekuatan dahsyat dalam membangun nasionalisme struktural menuju bangsa yang mandiri dan bermartabat. ${ }^{6}$ Sayangnya, beragam kasus perselisihan yang telah menumpahkan darah akibat sentimen etnis, ras, golongan, dan agama, terjadi di berbagai belahan dunia, termasuk Indonesia.

Memang, harus diakui bahwa pemahaman dan saling menghargai terhadap keberagaman etnik dan kultur tidak tumbuh dengan sendirinya dalam tatanan kehidupan masyarakat, tetapi harus disosialisasikan melalui tata aturan perundangan, dialog interaktif yang melibatkan seluruh komponen bangsa, media massa, dan melalui pendidikan multikultur yang dapat menfasilitasi terciptanya proses belajar mengajar tanpa adanya kendala perbedaan latar belakang kultural. ${ }^{7}$

Pendidikan multikultur adalah interdisiplin yang bertujuan untuk menciptakan kesempatan pendidikan yang sama antara siswa yang berasal dari suku, ras, status sosial, dan kelompok budaya yang berbeda. ${ }^{8}$ Tujuannya adalah untuk membantu siswa memperolah pengetahuan, sikap, dan keterampilan yang dibutuhkan guna menjalankan fungsi secara efektif dalam masyarakat demokratis yang pluralistik di samping berinteraksi, bernegosiasi, dan berkomunikasi dengan orang yang berasal dari kelompok yang berbeda agar menciptakan komunitas yang mampu bekerja sama dalam mencapai tujuan-tujuan yang lebih umum.

Sering tidak disadari bahwa berbagai kelompok budaya yang berbeda telah menggunakan pengetahuan matematika yang berbeda antara satu dengan lainnya. Kelompok petani dalam menanam jagung dapat menghitung luas area pertanian mereka dengan jumlah persediaan bibit jagung yang akan ditanam, atau mereka dapat membuat kalender untuk menandai musim, merencanakan fasilitas penyimpanan berdasarkan jumlah hasil pertanian, penataan kebun, dan sawah, seperti yang masih kita jumpai pada masyarakat Tolaki dengan beragam aktivitas di bidang ekono$\mathrm{mi}$, perikanan, pertukangan, hingga kerajinan seni budayanya dengan berbagai sentuhan geometri yang menarik. Bagi para arsitek, pengetahuan matematika dapat diterapkan di dalam konstruksi bangunan atau gedung, jembatan, dan sebagainya. Begitu juga halnya para penjahit pada saat membuat pola dengan menggunakan bahan kain atau kulit binatang ketika membuat pakaian atau sepatu. Oleh karena itu, etnomatematika di Indonesia sebenarnya bukanlah merupakan suatu pengetahuan baru melainkan sudah dikenal sejak diperkenalkan ilmu matematika itu sendiri. Hanya saja disiplin ilmu ini disadari setelah beberapa ilmuan memperkenalkan nama etnomatematika menjadi bagian dari ilmu matematika. Dengan demikian, yang dimaksud dengan etnomatematika adalah mate- 
matika yang diterapkan oleh kelompok budaya tertentu seperti suku tertentu, kelompok buruh, anak-anak dari masyarakat kelas tertentu, kelaskelas profesional, dan lain sebagainya. ${ }^{9}$

Dari definisi seperti ini, maka etnomatematika memiliki pengertian yang lebih luas dari hanya sekedar etno (etnik) atau suku dan jika ditinjau dari sudut pandang riset, maka etnomatematika didefinisikan sebagai antropologi budaya (cultural anthropology of mathematics) dari matematika dan pendidikan matematika. ${ }^{10}$ Dalam hubungannya dengan studi etnomatematika, penelitian ini menunjukkan ciri khususnya yakni mengintroduksi penelitiannya pada subjek yang sangat jarang dijadikan sebagai objek dan acuan dalam pendidikan. Dari latar belakang antropologi, penelitian ini memberikan warna baru bagi studi pengembangan matematika dalam latar budaya pada masyarakat Tolaki di Sulawesi Tenggara khususnya di Kendari dan Kabupaten Konawe Selatan. Oleh karena itu, yang menjadi permasalahan pokok sebagai bahan kajian dalam tulisan ini adalah aktivitas etnomatematika yang ada pada masyarakat Tolaki di Sulawesi Tenggara yang mencakup aktivitas membilang, mengukur, menentukan lokasi, merancang bangunan, bermain, dan aktivitas menjelaskan.

\section{ETNOMATEMATIKA DAN AKTIVITAS MEMBILANG}

Membilang berkaitan dengan pertanyaan "berapa banyak". Beberapa jenis alat yang masih digunakan oleh masyarakat Tolaki khususnya di daerah Kabupaten Konawe Selatan, untuk membilang meliputi: jari tangan, batu kerikil, potongan kayu atau bambu, tali rapia, dan rotan. Penggunaan batu dalam menghitung dapat dilihat, seperti aso, ruo, tolu, omba, o limo, dan seterusnya. Kata-kata membilang yang digunakan dalam upacara adat, tingkatan adat, kebiasaan sehari-hari yang digunakan tersebut dapat dinyatakan sebagai bilangan asli, genap, ganjil bahkan membilang jumlah "bentuk bulan" merupakan konsep bilangan yang didasarkan pada pengalaman dan kebutuhan hidup masyarakat Tolaki.

Pada upacara pepokolapasia terdapat ungkapan kata-kata membilang yang ditunjukkan dengan banyaknya lafalan do'a tahlil sebanyak 1000 kali dan ditandai dengan batu kerikil. Aktivitas ini dapat juga dijumpai pada saat penentuan besarnya mahar atau mas kawin yang ditentukan berdasarkan strata sosial seseorang. Strata sosial terlihat pada ukuran diameter kalo sara yang memiliki 3 jenis ukuran, yaitu jenis pertama, kalo yang memiliki diameter lebar bahu orang dewasa (lingkaran kalo dapat melewati dengan leluasa lebar bahu orang dewasa) diperuntukkan bagi golongan bangsawan atau anakia, jenis kedua adalah kalo yang berukuran 
tepat lebar bahu orang dewasa yang diperuntukkan untuk golongan menengah (rakyat biasa) atau tonomotuo, kalo seukuran diameter kepala orang dewasa yang diperuntukkan bagi golongan bawah/budak atau o ata. Penentuan besarnya mas kawin juga memiliki 3 tingkatan berdasarkan status sosial seseorang, yaitu: (1) pu'uno (dasar, pokok) yang dinilai dengan satuan o kasu (pohon atau batang), (2) wawono yang dinilai de-ngan satuan o mata (harta yang dinyatakan dengan sebuah, sepotong, seutas, selembar, dan seterusnya), (3) sara pe'ana yaitu seperangkat benda yang diperuntukkan bagi seseorang yang telah mengasuh mempelai wa-nita semenjak bayi, yang dinilai dengan seperangkat alat mandi bayi, selembar sarung, sebuah lampu tembok, dan sebuah uang logam yang setara dengan sebuah sendok makan.

Aktivitas matematika dari kegiatan tersebut di atas terlihat saat pengucapan do'a tahlil sebanyak 1000 kali yang ditandai dengan bayaknya batu kerikil, hal ini merupakan abstraksi dari perkawanan satu-satu ini akhirnya menjadi bilangan yang digunakan untuk keperluan praktis. Demikian pula halnya penentuan jumlah mahar bagi golongan anakia dan jumlah ini berlaku untuk seorang raja atau turunan raja: terdiri atas raja 16 kasu untuk syarat pokok adat (pu'uno), syarat wawono, tawano, atau ihino sebanyak 800, 400, dan 300 mata yang ditujukan bagi kalangan raja dan penguasa daerah. Satuan kasu yang berarti pohon atau batang dikonotasikan sebagai standar dasar/pokok dalam penentuan mas kawin berdasarkan tingkatan strata yang dapat dikenali dari ukuran diameter kalo sara yang digunakan. Adat pokok (pu'uno) terdiri atas: 1 pis kain kaci, 1 ekor kerbau, 1 buah gong, dan seuntai kalung emas yang akan dipersembahkan kepada mempelai wanita. Sedangkan satuan mata bermakna harta yang dinyatakan sebuah, setengah, seutas, selembar. Adat wawono, tawano, atau ihino berupa sarung yang jumlahnya bervariasi mulai dari 20, 40, dan 80 lembar sarung.

Nilai mas kawin untuk pu'no sebanyak 8 kasu dan juga berlaku sama untuk syarat wawono, tawano atau ihino, sedangkan yang tidak memiliki jabatan syarat pokok sebanyak 4 kasu, 160, 80, dan 40 mata. Golongan tonomotuo (masyarakat biasa) jumlah mahar bagi yang memiliki jabatan sebanyak 4 kasu dan 2 kasu bagi yang tidak memiliki jabatan. Golongan yang terakhir yaitu $o$ ata tidak ada permintaan untuk syarat pokok tetapi pada syarat wawono, tawano, ihino 10, 8, 4 mata atau 1-2 mata. Syarat sara pe'ana terdiri atas 1 buah baskom (wadah tempat memandikan bayi), 1 buah lampu tembok, sebuah uang logam yang dimaknai dengan sebuah sendok dari logam, 1 buah tempat cuci tangan, 2 lembar sarung yang diserahkan kepada seseorang yang pernah menjadi pengasuh mempelai 
wanita ketika masih kecil. Syarat pe'ana ini berlaku untuk semua tingkatan strata sosial. Nilai mas kawin tersebut masih berlaku hingga saat ini, walaupun nilai mas kawin tersebut terkadang hanya sebatas dimaknai terutama untuk syarat pokok wawono, di mana jumlah sarung yang seharusnya berkisar dari 20, 40, dan 80 lembar kain sarung dimaknai dengan 16 lembar sarung.

Penetapan nilai mas kawin berdasarkan strata seseorang merupakan aktivitas etnomatematika yang dimiliki oleh masyarakat Tolaki dalam kehidupan sehari-hari yang menopang pemahaman mengenai perbandingan atau rasio yang terlihat pada nilai mas kawin yang didasarkan tingkatan strata seseorang, hal ini menunjukkan bahwa etnomatematika merupakan bagian dari keseharian kita.

\section{ETNOMATEMATIKA DAN AKTIVITAS MENGUKUR}

Mengukur umumnya berkaitan dengan pertanyaan "berapa" atau dalam bahasa Tolaki "opio" (panjang, lebar, tinggi, waktu/lama, jumlah/banyak). Alat ukur yang digunakan selain takaran liter yang ada di pasaran, antara lain: tangan, gelas atau o'tonde, tali rotan, potongan kayu atau bambu, wadah karung beras ukuran $25 \mathrm{~kg}$ yang dibagi dua, kantong plastik dan wadah bekas sabun wings.

Pengukuran dengan menggunakan alat resmi yang beredar seperti liter dan gelas masih dijumpai di masyarakat Tolaki, tetapi tidak semua produk bahan makanan. Untuk keperluan bisnis jual beli di pasar tradisional, masyarakat menggunakan takaran resmi (liter) dan gelas untuk beberapa produk tertentu, sedangkan untuk non komersial mereka menggunakan sejenis alat yang disebut timboka dalam menakar beras atau sagu. Sagu yang diperjual belikan di pasaran dalam bentuk basu terkadang masyarakat menggunakan kantong plastik kecil sebagai alat menakar sagu yang dalam bahasa Tolaki disebut aso boku (satu kantong) dan dalam jumlah banyak sagu dikemas dalam karung bekas wadah beras ukuran 25 kg yang di bagi dua yang dikenal dengan ukuran aso basu tawaro (satu basu sagu).

Penggunaan tangan dalam mengukur sifatnya spontan, maksudnya apabila masyarakat tersebut hendak memasang pagar pembatas kebun, cukup menggunakan tangan sebagai pengganti meter lalu ukuran panjang tangan di transfer ke panjang rotan, selanjutnya dilakukan pengkuran luas kebun dan diberi tanda dengan tanaman jangka panjang.

Pemaparan di atas memperlihatkan bahwa praktek etnomatematika dalam hal pengukuran baik yang menggunakan anggota badan maupun kalo sebagai alat ukur dan pembatas merupakan manifestasi dari usaha 
masyarakat untuk memperoleh kejelasan luas lahan yang sesungguhnya yang dimiliki.

Sehubungan dengan pengukuran, kegiatan membuat o'tenda, tenunan sarung yang didominasi motif segitiga sama sisi memerlukan keahlian matematika tersendiri. O'tenda dan tabere yang dijahit membutuhkan ketekunan dan ketelatenan terutama saat membuat dan menyambung pola segitiga dan persegi yang berbeda ukuran. Penyusunan pola segitiga sama sisi pertama adalah 2-2 (2 segitiga berimpit horizontal dan 2 segitiga sama sisi berimpit veritikal), berikutnya 1-2-1 (1 bentuk persegi pengga-bungan kuning dan hitam, 2 segitiga siku-siku berwarna biru, 1 persegi penggabungan segitiga kuning dan hitam), selanjutnya pola persegi pan-jang 1-1-1 dengan dasar kain merah hingga penyambungan keseluruhan membentuk persegi panjang berukuran $4 \mathrm{~m} \times 3 \mathrm{~m}$. Ukuran pola warna-warni yang terdapat pada o'tenda disesuaikan dengan ketersediaan potongan-potongan kain perca dari sisa jahitan pakaian.

Aktivitas etnomatematika dari kegiatan tersebut di atas, selain berhubungan dengan kegiatan pengukuran yang mendominasi profesi penjahit, operasi penjumlahan dan perkalian merupakan bagian terpenting dari aktivitas ini menyangkut jumlah segitiga sama sisi yang dibutuhkan untuk mendapat luas o'tenda yang diinginkan. Dalam satu baris, berapa kali menyisipkan segitiga siku-siku berwarna biru sehingga diperoleh pola 1-2-1. Hal ini tidak jauh berbeda dengan kegiatan menenun sarung Tolaki dengan pola yang relatif sama, demikian pula halnya dengan teknik menganyam ambahi sorume.

Selain itu, beberapa sebutan yang menunjukkan urutan dari kecil ke yang lebih besar. Misalnya, (1) wadah minum: aso n'donde (satu gelas), aso mango (satu mangkok), (2) bulir padi: aso hae (satu ikat kecil), aso ulu $=4$ hae (satu ikat besar seukuran pertemuan dua lingkaran tangan orang dewasa), (3) daun sirih: aso lawa (satu lembar), aso mbulu (separuh), (4) sagu: aso litere, aso boku (satu kantoong plastik kecil), aso ganta, aso basu, (5) nasi: aso pusu (satu genggam nasi), aso mbingga (sepiring nasi), aso ngguro (sepanci nasi), (6) biji-bijian: aso boto (sebiji), aso katoa, (7) buah-buahan: aso ase (satu sisir pisang), (8) kalung/rantai: aso eno wulaa (seuntai kalung).

Mengukur yang dimaksud berkenan dengan ukuran panjang dan berat atau menakar. Bagi masyarakat Tolaki di lokasi tempat penulis meneliti, pengukuran yang mereka lakukan sudah menggunakan alat standar yang ditetapkan pemerintah untuk konsumsi komersial, sedangkan untuk konsumsi sendiri umumnya mereka menggunakan anggota tubuh, potongan kayu atau benda lain (wadah sabun wings). Informan Titi (31 tahun), Werika (48 tahun) merasa lebih tepat mengukur beras dengan 
menggunakan timboka (wadah sabun wings) dalam menakar beras dari pada menggunakan takaran liter produk kosmos yang mereka beli di toko. Menurut kedua informan penggunaan timboka dalam menakar beras akan lebih tepat takaran nasi yang dihasilkan dari pada menggunakan takaran produk kosmos yang mereka miliki.

Penentuan jarak dengan menggunakan langkah kaki seperti yang dilakukan oleh siswa dalam mengukur jarak garis star dengan lingkaran pada permainan baguli yang berjumlah 7 langkah. Menakar (mengukur) dan membilang merupakan dua kegiatan yang tidak dapat dipisahkan. Pelaksanaan kegiatan pengukuran biasanya disertai dengan kegiatan membilang.

Pengukuran dengan menggunakan salah satu anggota badan masih dapat dijumpai pada masyarakat Tolaki saat pembuatan lumbung padi atau o'ala. Luas o'ala yang akan dibangun, disesuaikan dengan banyaknya hasil panen yang akan disimpan, dan tinggi tiang penyangga o'ala setinggi badan $\pm 180 \mathrm{~cm}$, tinggi dalam lumbung juga $\pm 180 \mathrm{~cm}$, berbentuk persegi panjang dengan luas $240 \mathrm{~cm} \times 2 \mathrm{~m}$. Di setiap pertengahan tiang peyangga $o^{\prime}$ ala direkatkan plastik terpal licin yang berfungsi untuk meng-hindari hama tikus.

Selain sebagai simbol adat, ukuran besar kecilnya kalo dapat dijadikan acuan dalam penentuan jumlah mas kawin atau mahar. Bentuk kalo ini juga identik dengan salah satu jenis tarian khas masyarakat Tolaki, yaitu lulo atau molulo dimana semua peserta yang ikut dalam tarian tersebut membentuk lingkaran. Ukuran lingkaran tarian lulo ini berdasarkan banyak peserta yang ikut dalam permainan tersebut yang berubah-ubah mengikuti pola langkah kaki yang terdapat pada tarian lulo tersebut yang dikuti oleh alunan suara musik atau tabuhan gong. Perpindahan langkah kaki dari arah kanan, kiri, depan dan ke belakang masing-masing dua langkah, dan saat perpindahan langkah ke depan sebanyak dua langkah, maka diameter permainam dan lulo tersebut akan mengecil sebanyak dua langkah, dan sebaliknyapun demikian. Permainan ini akan terus berputar searah jarum jam dan seluruh gerakan kaki pada tarian lulo ini serempak dan seragam mengikuti alunan musik pengiringnya.

Dengan demikian, nilai matematika yang terdapat pada tarian lulo terdapat pada aturan langkah dengan pola 3-2-2-2 (ke kanan 3 kali - ke kiri 2 kali - mundur 2 kali - kembali ke kiri 2 kali), diameter lingkaran lulo berubah besar/kecil sebanyak 2 langkah, ukuran lingkaran tarian bergantung pada banyaknya peserta tarian dan faktor ini berhubungan dengan ruang, sedangkan durasi musik yang mengiringi tarian lulo tersebut berhubunga dengan waktu. 


\section{ETNOMATEMATIKA DAN AKTIVITAS MENENTUKAN LOKASI}

Banyak konsep dasar geometri yang diawali dengan menentukan lokasi yang digunakan untuk rute perjalanan, menentukan arah tujuan atau jalan pulang dengan tepat dan cepat. Beberapa masyarakat memiliki kode atau simbol tertentu dalam menetapkan lokasi di lingkungannya.

Penentuan lokasi bagi masyarakat Tolaki juga digunakan untuk menentukan batas-batas wilayah, ladang, sawah, dan kebun. Selain itu, tanda-tanda alam seperti gunung, batu besar, hamparan sungai masih dijadikan sebagai batas wilayah utamanya hamparan tanah leluhur mereka yang pernah memerintah di daerah setempat. Hal ini dapat dijumpai di daerah Waturapa yang saat ini menjadi daerah eksplorasi tambang nikel, dan menjadi salah satu lahan yang diwarisi oleh sejumlah keluarga yang diantaranya bermarga Toondu, Samaga, Rombe, Pagala. Kepemilikan lahan oleh sekelompok keluarga tersebut diakui oleh pemerintah setempat berdasarkan tanda alam tersebut yang digunakan sebagai pembatas kepemilikan lahan yang telah ada sejak ratusan tahun yang lalu dan turunan mereka saat ini mewarisinya sebagai tanah leluhur.

Selain menggunakan batas alam sebagai batas lahan, penggunaan tanaman tahunan seperti sagu, kapuk, beringin, sagu, pohon jati, dan rotan masih digunakan sebagai batas lahan. Areal yang ditanami sagu sepanjang sungai dan rawa merupakan tanah milik warisan sampai beberapa generasi, karena tanaman sagu sukar punah. Selain itu tanaman sagu ini merupakan pelengkap mas kawin selain kerbau, gong, tempayan, dan seuntai kalung emas.

\section{ETNOMATEMATIKA DAN AKTIVITAS MEMBUAT RANCANG BANGUN}

Gagasan lain dari etnomatematika yang bersifat universal dan penting adalah kegiatan membuat rancang bangun yang telah diterapkan oleh semua jenis budaya yang ada. Jika kegiatan menentukan letak berhubungan dengan posisi dan orientasi seseorang di dalam lingkungan alam, maka kegiatan merancang bangun berhubungan dengan semua benda-benda pabrik dan perkakas yang dihasilkan budaya untuk keperluan rumah tinggal, perdagangan, perhiasan, peperangan, permainan, dan tujuan keagamaan.

Pembuatan alat pertanian seperti: parang, kampak, tugal, sabit, lesung, alu, tampi, o saku, tombak. Mereka juga telah mampu mendirikan bangunan rumah tinggal, lumbung padi, tempat tidur, meja, dan kursi. Konsep matematis terutama membilang pada kegiatan merancang bangun 
dapat dilihat pada perencanaan dan pelaksanaannya. Untuk pembuatan lumbung padi, masyarakat di desa Watumerembe tidak membuat desain khusus sebelum membuat lumbung padi, dan ukurannya berdasarkan banyaknya padi yang mereka miliki, umumnya lumbung padi masyarakat berukuran $2 \mathrm{~m} \times 2 \mathrm{~m}$.

Pembuatan rumah tinggal baik yang permanen (bahan bangunan dari batu bata) maupun semi permanen, dibutuhkan sketsa dan teknik pembuatannyapun sudah mengikuti cara-cara pembangunan rumahrumah yang sering kita saksikan, walaupun ada beberapa tukang yang terlibat dalam rancang bangun tersebut belum pernah mengenyam pendidikan formal tapi memiliki keahlian yang tidak kalah dengan keahlian yang dimiliki sarjana arsitektur.

Beberapa bentuk bangun dan motif dengan desain geometri yang mendominasi beberapa hasil kerajinan tangan masyarakat Tolaki mencerminkan pola-pola geometri seperti simetri yang terdapat pada anyaman tikar, motif tenunan sarung, serta perlengkapan lain sehari-hari.

Desain motif yang mendominasi beberapa kerajinan tangan masyarakat memiliki pola aturan matematik seperti pola 1-1, 1-3-1, dan seterusnya yang berpengaruh pada hasil desain motif yang dihasilkan akan lebih indah dan menarik. Demikian pula halnya bentuk desain rumah adat masyarakat Tolaki, walaupun saat ini masyarakat sudah banyak yang beralih mendirikan rumah permanen, tetapi dengan corak dan model desain atap rumah masih tetap mengikuti bentuk asli rumah adat.

\section{ETNOMATEMATIKA DAN AKTIVITAS BERMAIN}

Beberapa jenis permainan tradisional yang memiliki beberapa bangun geometri terdapat pada masyarakat Tolaki dapat dilihat pada halaman 29 Gambar 1. Permainan tersebut adalah: permainan robot, asi, lamari, disco, dan baguli.

Permainan robot. Permaianan ini dapat dimainkan oleh 2, 4, dan 6 orang anak perempuan dan laki-laki secara bergiliran. Alat yang digunakan dalam permainan ini adalah sebuah batu pipih yang ukurannya sebesar telapak tangan anak yang berbentuk segitiga, persegi, atau lingkaran dan batu ini dimiliki oleh masing-masing pemain yang diletakkan di garis kotak pertama sebagai awal memulai permainan. Pergiliran pemain dilakukan dengan cara pengundian atau anak-anak mengenalnya dengan istilah sut yang dilakukan oleh dua orang anak dengan perhitungan angka undian sampai 5 dan pola pengundian ini sama dengan turnamen tabel yang sering dilakukan dalam beberapa turnamen resmi. 
Cara memainkannya: permainan diawali dengan meletakkan batu di kotak pertama dan pemain melompat dengan sebelah kaki tanpa berpijak di kotak tempat batu diletakkan. Dua pasang persegi panjang yang berimpit dapat dipijakkan kedua kaki selama tidak terdapat batu pada salah satu persegi. Permainan akan berakhir apabila menginjak kotak tempat batu diletakkan atau melempar batu ke dalam kotak dan mengenai batu teman yang lain. Selanjutnya batu akan berpindah secara bertahap searah jarum jam pada daerah persegi dan setiap perpindahan batu, pemain berpijak dengan sebelah kaki (kecuali yang dua persegi panjang berimpit) sampai di puncak yang berbentuk setengah lingkaran. Demikian seterusnya sampai batu akan tiba di puncak permainan robot. Perpindahan batu dilakukan dengan melemparkan dengan tepat ke dalam setiap kotak. Nilai matematika yang terdapat pada permainan robot ini adalah pengenalan bentuk bangun datar yang dimiliki oleh pola permainan tersebut, kelipatan dan faktor bilangan merupakan nilai matematika yang terdapat pada aturan jumlah pemain yang dimulai dari 2, 4, dan 6 orang. Pokok bahasan kelipatan dan faktor bilangan merupakan salah satu materi pelajaran matematika di Sekolah Dasar.

Permainan Lamari. Permainan ini memiliki kesamaan dengan permainan robot. Perbedaannya hanya terletak pada cara memindahkan batu dari satu kotak ke kotak yang lain. Perpindahan batu dilakukan dengan cara menggeser batu dengan ujung depan sebelah kaki secara berhati-hati agar batu tidak melewati kotak ataupun mengenai batu yang lain.

Permainan disco. Permainan ini memiliki kesamaan dengan kedua permainan di atas, bedanya hanya cara berpijak pada setiap kotak. Perpindahan kaki di setiap kotak dilakukan secara bergantian oleh kedua kaki pada kotak yang terletak di tengah. Ketiga jenis permainan (disco, robot, dan lamari) memiliki kesamaan aturan dalam permainan, demikian halnya sejumlah aturan dalam hal jumlah pemain yang terlibat pada ketiga jenis permainan tersebut yang selalu berpasangan dimulai dari 2, 4, dan 6 orang anak. Nilai matematika yang terdapat pada ketiga permainan tersebut adalah kelipatan dan faktor bilangan yang merupakan bagian materi pembelajaran matematika yang diajarkan di kelas-kelas tinggi.

Permainan baguli atau kelereng. Kelereng yang digunakan adalah kelereng yang banyak dijual dipasaran dan di toko-toko mainan. Baguli terbuat dari kaca dan mudah mental apabila dihempaskan di atas lantai. Pemainan baguli dapat dimainkan oleh 2 sampai 10 orang anak.

Permainan ini dapat dilakukan oleh anak perempuan maupun lakilaki. Aturan main diberlakukan setelah semua peserta melemparkan kele- 
reng pada titik pusat garis. Jarak titik star tempat melempar kelereng sebanyak 7 langkah. Setelah kelereng dilempar ke dalam lingkaran, kemudian akan diukur jarak setiap kelereng terhadap garis lurus titik pusat dan selanjutnya diurutkan dari jarak yang terdekat hingga yang terjauh dari garis pusat.

Pada permainan baguli jumlah pemain berjumlah 2 sampai 10 orang anak, bahkan pada areal halaman yang luas pemain dapat mencapai 12 orang. Aturan mengenai siapa yang berhak memulai permainan berdasarkan jarak kelereng yang terdekat dengan garis tengah pada permainan baguli tersebut sebagai pemain 1, selanjutnya pemain ke 2 yang berada tidak jauh dari baguli pertama, dan seterusnya demikian sehingga akan membentuk pola urutan bilangan asli dari 1, 2, 3,..,10. Urutan bilangan ini dikenal sebagai bilangan bulat positif. Perolehan poin dari setiap sentilan baguli yang berhasil mengenai baguli yang lain akan memperoleh 3 kelereng (sebelumnya telah ditetapkan bahwa untuk setiap sentilan yang berhasil mengenai kelereng lawan memperoleh 3 butir baguli). Sehingga apabila seorang pemain berhasil menyentilkan bagulinya dan mengenai kelereng lawan sebanyak 5 kali berarti pemain tersebut memperoleh kelereng sebanyak $5 \times 3=15$ kelereng ( 5 adalah banyak sentilan yang berhasil mengenai baguli lawan, dan 3 adalah banyak kelereng yang diperoleh untuk setiap sentilan). Tentunya setiap pemain memiliki kesempatan yang berbeda dalam perolehan jumlah baguli, tergantung kemahiran pemain dalam menyentilkan bagulinya. Perolehan baguli yang berbeda-beda tersebut, dijadikan perbandingan dalam hal perolehan baguli dari yang terbanyak sampai yang tidak memperoleh baguli sama sekali. Sejumlah aturan dan tata cara dalam permainan baguli ini sangat erat kaitannya dengan materi "membandingkan dan mengurutkan bilangan bulat" pada pembelajaran matematika formal di kelas yang merupakan salah satu cara dalam mengimplementasikan pendekatan etnomatematika yang berlatar permainan tradisional siswa.

Melakukan operasi penjumlahan dan perkalian bilangan bulat. Jika dalam aturan permainan baguli ditetapkan 3 butir per sekali sentilan baguli yang mengenai kelereng lawan, maka untuk sentilan sebanyak 5 kali yang berhasil mengenai kelereng lawan, akan memperoleh kelereng sebanyak $5 \times 3=15$ butir kelereng. Konsep perkalian disini merupakan penjumlahan berulang. Hal ini merupakan cara praktis dalam mengajarkan materi operasi penjumlahan dan perkalian bilangan bulat.

Pemain yang dapat menyentilkan bagulinya terlebih dahulu adalah pemain dengan posisi baguli terdekat dengan diameter garis baguli sebagai 
pemain 1, dan seterusnya secara berurutan hingga membentuk pola 1, 2, 3, ...,10 yang merupakan urutan bilangan asli. Hal ini merupakan salah satu cara dalam mengenalkan konsep bilangan asli pada siswa dan merupakan salah satu nilai matematika yang terdapat pada permainan baguli.

\section{ETNOMATEMATIKA DAN AKTIVITAS MENJELASKAN}

Membuat penjelasan merupakan kegiatan yang mengangkat pemahaman manusia yang berkaitan dengan pengalaman yang diperoleh dari lingkungannya yang berkenaan dengan kepekaan seseorang dalam membaca gejala alam. Dengan demikian aktivitas lingkungan yang ada senantiasa menggunakan bilangan. Dalam matematika, penjelasan berkaitan dengan "mengapa" bentuk geometri itu sama atau simetri, mengapa keberhasilan yang satu merupakan kunci keberhasilan yang lain, dan beberapa gejala alam di jagad raya ini mengikuti hukum matematika. Dalam menjawab pertanyaan ini digunakan simbolisasi, misalnya dengan bukti nyata.

Tradisi yang masih dilakoni oleh masyarakat Tolaki dalam beberapa acara ritual seperti pepokolapasia (malam penghabisan) dalam upacara ta'ziah terdiri dari beberapa imam dan pemuka adat yang melafalkan do'a tahlil sebanyak 1000 kali. Penghitungan jumlah do'a tahlil ditandai dengan batu kerikil sebagai pengganti tasbih, dan diakhir acara batu kerikil tersebut dihantar ke keburan sebagai bagian dari batu nisan permanen yang ditanam diakhir acara. Perayaan acara ini dilakukan sebagai bentuk penghargaan keluarga kepada orang tua yang telah mendahului.

Pada permainan tradisional terdapat konsep-konsep membilang. Konsep tersebut terkandung dalam jawaban, berapa orang pemain yang diperlukan untuk tiap-tiap jenis permainan? Berapa kotak yang dibutuhkan untuk membentuk pola permainan robot, lamari, disco, dan asi? Semua ini memiliki penjelasan berdasarkan aturan main yang telah ditetapkan dan apabila seorang guru mampu mengkreasikan dengan memanfaatkan tatanan kebudayaan masyarakat setempat akan mempunyai pengaruh yang besar dalam pembelajaran matematika.

\section{SIMPULAN}

Etnomatematika pada etnis Tolaki tergambar pada enam aktivitas masyarakat. Keenam aktivitas tersebut yakni pertama, aktivitas membilang yang berkaitan dengan pertanyaan "berapa banyak", seperti yang terdapat pada upacara pepokolapasia terdapat ungkapan kata-kata membilang dalam menandai jumlah do'a tahlil yang diucapkan. Kedua, aktivitas mengukur berkaitan dengan pertanyaan "berapa" (panjang, lebar, tinggi, waktu/la- 
ma, jumlah/banyak). Beberapa alat ukur standar maupun tradisional masih dapat dijumpai pada masyarakat Tolaki, selain itu penggunaan anggota badan (tangan, bahu) masih digunakan dalam melakukan pengukuran. Sejumlah aktivitas masyarakat pada berbagai profesi seperti: petani, tukang kayu, penjahit dan kegiatan profesional lainnya, memiliki keahlian tersendiri dalam hal pengukuran. Ketiga, aktivitas menentukan lokasi berhubungan dengan rute perjalanan, menentukan arah atau tujuan pulang dengan cepat dan tepat dengan memberikan kode atau simbol tertentu dalam menentukan batas-batas wilayah, ladang, sawah, dan kebun. Keempat, aktivitas merancang bangun. Kegiatan ini berhubungan dengan semua benda-benda budaya untuk beberapa keperluan seperti: rumah tinggal, perdagangan, perhiasan, peralatan peperangan, permainan, dan tujuan keagamaan. Nilai matematika dari kegiatan ini berkaitan erat dengan dimensi. Kelima, aktivitas bermain (tradisional/rakyat). Dalam permainan lamari, disko, robot memiliki aturan permainan yang sama yaitu jumlah pemain yang genap dimulai dari 2, 4, 6, dan seterusnya. Nilai matematika yang dapat diperoleh dari permainan ini berkaitan dengan pokok bahasan kelipatan dan faktor bilangan, selain itu pola permainan ini memiliki sejumlah bangun geometri dan dapat merupakan salah satu alat peraga dalam mengenalkan konsep bangun datar pada siswa sekolah dasar. Sedangkan permainan baguli memiliki aturan jumlah pemain yang cenderung ganjil, nilai matematika yang terdapat pada permainan ini yaitu: membandingkan dan mengurutkan bilangan bulat, melakukan operasi penjumlahan dan perkalian bilangan bulat, pengenalan bilangan asli, pengukuran dengan menggunakan konsep keliling dan luas. Keenam, aktivitas menjelaskan (penjelasan) merupakan kegiatan yang mengangkat pemahaman manusia yang berkaitan dengan pengalaman yang diperoleh dari lingkungan yang berkaitan dengan pertanyaan "mengapa" keberhasilan yang satu merupakan kunci keberhasilan yang lain.

\section{CATATAN AKHIR}

1. Suryadinata, Etnis Tionghoa dan Pembangunan Bangsa, dikutip secara tidak langsung dalam Achmanto Mendatu, Strategi Meningkatkan Kompetensi Guru dalam Melaksanakan Pendidikan Multikultural, 2010, http:/ / smart-psikologi.blogspot.com/2007/08/pendidikan-multikultural.html, h. 2.

2. Marwah Daud Ibrahim, Planning and development of Indonesia's domestic communications satellite system Palapa, 2005, dikutip secara tidak langsung dalam Muhammad Yaumi, Using Distance Education to Deliver English Instruction in Indonesia, A Graduate Research Paper. USA: University of Northern Iowa, 2006, h. 3.

3. Ubed Abdillah, Politik Identitas Etnis, Magelang: Indonesia Tera, 2001, h. 15.

4. David Matsumoto, Culture and Psychology, California: Brooks/Cole Publishing 
Co., 1996, h. 21.

5. Djamaluddin Ancok, Modal Sosial dan Kualitas Masyarakat, Pidato Pengukuhan Jabatan Guru Besar pada Fakultas Psikologi UGM, tidak diterbitkan, 2003, h. 4.

6. Achmanto Mendatu, Strategi Meningkatkan Kompetensi Guru dalam Melaksanakan Pendidikan Multikultural, 2010, http://smartpsikologi.blogspot.com/2007/ 08/pendidikan-multikultural.html, h. 4.

7. Ibid, h. 1.

8. Allyn and Bacon, Multicultural Education: Issues and Perspectives, Third Edition, Edited by James A. Banks and Cherry A. McGee Banks, A Viacom Company, Needham Heights, MA 02194. USA, 1997, h. 3.

9. Gloria Gilmer, A Definition of Ethnomathematics, http://web.nmsu.edu/ ps cott/isgem111.htm.

10. U. D'Ambrosio, Ethnomathematics Link between Traditions and Modernity, Published by: Sense Publishers, P.O. Box 21858, 3001 AW Rotterdam, The Netherlands, 2006, h. 1.

\section{DAFTAR PUSTAKA}

Abdillah, U., Politik Identitas Etnis, Magelang: Indonesia Tera, 2001.

Allyn and Bacon, Multicultural Education: Issues and Perspectives, Third Edition, Edited by James A. Banks and Cherry A. McGee Banks, A Viacom Company, Needham Heights, MA 02194. USA, 1997.

D'Ambrosio, U., Stakes in Mathematics Education for the Societies of Today and Tomorrow. One Hundred Years of L'Enseignement Mathématique, Moments of Mathematics Education in the Twentieth Century. Proceedings of the EMICMI Symposium, Geneva, in Daniel Coray et al (Eds). L'Enseignement Mathématiques, Genève, 302-316, 2003.

D'Ambrosio, U., What is ethnomathematics, and how it help children in schools? Volume 7(6) start page 308. Artikel online, http://www.sensepublishers. Com, diakses pada tanggal 20 Agustus 2008.

D'Ambrosio. U., Ethnomathematics Link between Traditions and Modernity. Published by: Sense Publishers, P.O. Box 21858, 3001 AW Rotterdam, The Netherlands, 2006.

Danim, Sudarwan, Menjadi Peneliti Kualitatif, Bandung: Pustaka Setia, 2002.

Gilmer, Gloria, A Definition of Ethnomathematics. Artikel Online, http:/ / web.nmsu.edu/ pscott/isgem111.htm. Diakses pada tanggal 20 Agustus 2008.

Mendatu, Achmanto, Strategi Meningkatkan Kompetensi Guru dalam Melaksanakan Pendidikan Multikultural. Artikel Online (http://smartpsikologi.blogspot.com/2007/08/pendidikan-multikultural.html). Diakses pada tanggal 20 Agustus 2008.

Sayu, Silvia, dkk., Pengembangan Bahan Ajar Matematika yang Bernuansa Etnomatematika dalam Suku Dayak Kanayat'n di Kalimantan Barat untuk membantu Siswa Sekolah Dasar Mempelajari Konsep Matematika. 2008. Penelitian Fundamental Tahun anggaran 2009. Tidak diterbitkan.

Yaumi, Muhammad, Using Distance Education to Deliver English Instruction in Indonesia. A Graduate Research Paper. UNI. USA, 2006. 